\title{
CARVALHO, Bernardo. Reprodução. São Paulo: Companhia das Letras, 2013. 168 p.
}

\section{Reprodução e a caixa de Pandora do julgamento humano}

Reprodução (2013) é o décimo primeiro livro de Bernardo Carvalho, um dos autores mais reconhecidos e premiados da literatura brasileira contemporânea. Pela procedência, podemos esperar uma estruturação complexa, exigente, consciente de sua forma, e pouco interesse por convenções - as de mercado, da sedução narrativa ou as da representação realista. Estamos preparados para conhecer o estudante de chinês, o protagonista do romance, que, prestes a embarcar para Xangai, encontra, no aeroporto, a antiga professora que o abandonara, como ele gosta de lembrar, no meio da lição 22 do curso intermediário do idioma.

$\mathrm{Na}$ trama, a professora carrega pela mão uma criança, e, na fila do check-in, é abordada e levada embora por um policial. Em seguida, também o estudante é detido e interrogado pela polícia federal. Neste interrogatório, iniciado na terceira página do romance, o leitor é abduzido para o fluxo contínuo do tecido discursivo da obra, apresentado em seu aspecto mais destacado e pouco usual: Reprodução é dividido em três partes, que são em grande medida diálogos sem interlocutor, com pouca ação direta. Dois deles são proferidos pelo protagonista, e outro é escutado por ele através da divisória da sala onde está encerrado, e parece ser de uma delegada da Polícia Federal. Por meio desses grandes discursos, quase monólogos, nós vamos apreendendo o enredo, intrincado e atravessado de incertezas. A mulher do estudante o deixou para viver com um quiroprático americano que, ao contrário do ex, queria ter filhos. A delegada masoquista só tem prazer na humilhação, e é por isso que, depois de descobrir os grupos de encontros, substituiu-os pela igreja. Nada disso acontece com cena e diálogos diretos; quase tudo em Reprodução é contado por esses dois narradores dramatizados e incansáveis.

O peculiar nesta construção é como ela mimetiza e reproduz o palavrório incessante da mídia e das redes sociais pelo qual somos soterrados cotidianamente. São frases de efeito, clichês, bordões - aos borbotões. O discurso do protagonista, em especial, replica, de forma inconsciente e mesmo incoerente, uma série de lugares-comuns sobre todo e qualquer assunto, a China, o futuro, horóscopo, Jesus, a economia mundial, milionários brasileiros, aquecimento global. Sem contar os preconceitos, em declarações auto-acusatórias, como em "Não tenho preconceito nem contra preto, quanto mais contra judeu, que em geral é branco" (CARVALHO, 2013, p. 39). Enquanto outras obras de Carvalho são narradas por sádicos, desmemoriados, psicóticos, doentes do cérebro, os 'bêbados' e 'sonâmbulos' de seu romance de 1996, em diferentes escolhas de limitação moral, mental e cognitiva da voz narrativa, Reprodução elege como narrador não-confiável uma espécie de comentarista de internet desinformado.

Com o narrador em primeira pessoa, o autor nos cola à consciência do estudante falastrão, e quando se abre essa caixa de Pandora, somos convidados a saltar de um rudimento de opinião à outra, como num fluxo de consciência voltado ao exterior. As opiniões são apresentadas, como o narrador se orgulha de exibir, como instruídas.

Não só revista semanal. Jornal também. Leio blog. Acompanho. Sei do que estou falando. Leio os colunistas. É! Colunistas de jornal, sim, senhor. Colunistas, articulistas, cronistas. Revistas, jornal, blog. Gente preparada, que fala com propriedade, porque sabe o que está dizendo (idem, p.38).

A confiança que o protagonista parece ter no enciclopedismo de tais respeitáveis fontes de conhecimento nos faz pensar se é por causa da abundância de opiniões formadas que o autor nos nega a voz do outro, do policial que o interroga, da professora, de qualquer outro personagem além de quem fala. Reprodução aponta para um universo discursivo em que o outro não tem voz.

Seguindo a consciência dos especialistas em generalidades da internet, o narrador de Reprodução não pode sequer ter nome próprio, ele é o "estudante de chinês". Ao lado dele, temos uma delegada, um agente, um índio, uma professora. A tipificação sugerida na identificação dos personagens é sintomática, já que os tipos são o contrário de uma consciência autônoma, individual, que se descole de um grupo ou de uma classe a que pertença. É o oposto de uma personagem redonda, 
na famosa distinção de E.M. Forster, que é montada por mais de uma ideia ou qualidade e por isso expressa maior grau de ambiguidade e elaboração (FORSTER, 1974).

No caso de Reprodução, as personalidades por trás do discurso têm uma construção rica de informações sutis. Observe o caso do estudante, ex-analista de mercado financeiro, que não quer filhos, é divorciado, sofre com isso. Ele tem um passado, até um tataravô que foi plantar chá em Santa Cruz e acabou mascate no Rio de Janeiro. Poderíamos dizer que o personagem/narrador exibe traços de uma personalidade complexa, mas que é soterrada pela própria voz exuberante da narração, que não se volta para dentro. É o mundo exterior, recriado na voz do personagem como um espelho quebrado em muitos cacos, que enseja a lembrança de fragmentos de uma história pessoal, e não, como acontece na tradição realista moderna, a identidade do personagem que, tendo uma origem, uma trajetória e uma personalidade, erige um mundo e um modo particular de vê-lo.

É para esse processo de desconstrução da identificação que a nomeação por tipos, onipresente no romance, contribui. Mesmo no caso da professora de chinês, que tem a graça revelada - Liuli, cujo significado pode variar de "cristal" a "mendiga miserável" (ibidem, p.25) -, o placar de aparições do nome de batismo é menor do que o da identificação pela profissão.

Os tipos, índices de uma construção de personagem estereotipada e superficial, tencionam a decodificação da profundidade dos personagens do romance. Da mesma maneira, tantos comentários sobre o universo exterior fazem com que a narração em primeira pessoa diminua seu efeito de subjetividade. Se, do ponto de vista da narratologia, estamos defronte um narrador-personagem de modo protagonista, que narra a partir de uma perspectiva fixa e central dentro da história, em Reprodução este não se constrói por qualidades a ele atribuídas diretamente ou por meio de cenas, e sim por um modo de ver o mundo que é muito pouco individual.

\section{Uma poética da incerteza}

Em comum com outros livros de Bernardo Carvalho, pode-se apontar em Reprodução uma poética da incerteza, em que a realidade é sempre mediada pelas percepções de personagens limitados, nunca muito confiáveis, em situações que tornam especialmente difícil remontar a um mundo de certezas e de totalidade. A narrativa não raro termina inconclusa, fragmentária, às vezes mesmo espectral, como no caso, em Reprodução, da história da delegada que não sabemos bem nem se é quem ela parece ser, ou se é fruto da imaginação e da ignorância do estudante que a escuta.
Embora o protagonista afirme e declare e explique todo e qualquer assunto, o discurso quilométrico que desfia não explica justamente o que esperamos de uma narrativa comum: o seu sentido, seu começo, meio e fim. Ao cabo, uma explicação para o que está acontecendo. Explicações e definições, de verdade, é o que o romance se nega a dar. A delegada matou o filho? A professora realmente era uma mula de traficantes, carregando a filha de traficantes assassinados? A professora quer salvar a criança? A criança está condenada ao sofrimento e por isso chora sem parar no final?

O autor envolve o leitor em brumas que impossibilitam a instauração de uma realidade clara. Primeiro, vemos o mundo pelos olhos do personagem, e esse personagem é confuso e contraditório, não entende o que vê. Como nós entenderíamos?

Se a escolha de perspectiva e de um narrador nãoconfiável contribui para a impossibilidade de o leitor resolver a narrativa, esse obstáculo é acentuado pela instauração de uma babel de línguas no ambiente. $\mathrm{O}$ estudante é convocado ou se convoca a falar em chinês, língua que não domina nem dominará. Para coroar a dificuldade de comunicação, a segunda parte do romance nos presenteia com uma parede entre quem fala e quem escuta, a divisória entre as salas de interrogatório.

E, assim como é incapaz de reconhecer os tons em mandarim, só lhe resta imaginar, agora na sua própria língua, por conta de uma deficiência de realidade, com o ouvido colado à divisória ordinária, o que deseja ouvir na sala ao lado (CARVALHO, 2013, p. 58).

Tudo é posto para que não saibamos, não possamos dizer, desvendar, reconstruir o mundo da narrativa. Talvez por isso haja tamanha tensão no livro entre acreditar e não acreditar, crentes e descrentes, padres, missionários, agentes infiltrados, em meio a ateus como o estudante de chinês. Sua fé cômica em uma salvação só se encontra na China. Só a China, o símbolo da alteridade, do exótico, é que pode ainda trazer alguma esperança. Só na China James Joyce é best-seller, diz o estudante, desinformado.

Na bibliografia de Carvalho, a combinação entre a estruturação narrativa e a temática da ausência de sentido de Reprodução remete especialmente a Teatro, publicado em 1998. Também se valendo de diálogos sem interlocutor, Teatro aborda os temas da paranóia, da comunicação, da representação e da busca, sempre fracassada, de um sentido último.

Pelo desinteresse pela "verdade dos fatos", pela impossibilidade de reconstruir a narrativa, pelo gosto pela ambiguidade, pela escolha por um narrador não-confiável por uma limitação cognitiva e afetiva, incoerente, desacreditado e desesperançoso, Reprodução 
é uma peça exemplar da poética de Bernardo Carvalho - e mais uma vez em franco diálogo com o projeto literário de um de seus mais admirados autores, Thomas Bernhard. Quando era ele mesmo um articulista de jornal, da Folha de São Paulo, Carvalho escreveu que entre as maiores contribuições do autor de $O$ náufrago estava o fato de o austríaco deixar claro que, por mais espontânea que pareça, toda manifestação literária é artifício. Uma provocação sobre a ignorância e as suas formas,
Reprodução mostra seus artifícios e nos faz provar, como reflete o protagonista nas páginas finais, do mal-entendido como forma de comunicação.

Moema Vilela Pereira PUCRS

Recebido: 14 de fevereiro 2014 Aprovado: 22 de maio 2014 Contato:moemavilela@gmail.com 